Pesq. Vet. Bras. 38(5):981-990, maio 2018

\title{
Bone quality evaluation of experimental osteometabolic disease in Pantanal alligators (Caiman yacare) by High Resolution Computerized Microtomography $(\mu \mathrm{CT})^{1}$
}

\author{
Marciel Becker², Marcos A. Souza², Luiz G. Moraes², Gustavo S. Silva ${ }^{3}$, \\ Nadia A.B. Antoniassi ${ }^{4}$, Roberto L. Souza ${ }^{5}$ and Edson M. Colodel ${ }^{5 *}$
}

\begin{abstract}
Becker M., Souza M.A., Moraes L.G., Silva G.S., Antoniassi N.A.B., Souza R.L. \& Colodel E.M. 2018. Bone quality evaluation of experimental osteometabolic disease in Pantanal alligators (Caiman yacare) by High Resolution Computerized Microtomography ( $\mu \mathrm{CT})$. Pesquisa Veterinária Brasileira 38(5):981-990. Faculdade de Medicina Veterinária, Universidade Federal de Mato Grosso, Av. Fernando Corrêa da Costa 2367, Bairro Boa Esperança, Cuiabá, MT 78068-900, Brazil. E-mail: moleta@gmail.com

Computerized microtomography is the gold standard examination for the evaluation of the three-dimensional bone structure. This experiment was developed to evaluate the structure and bone quality of Caiman yacare with metabolic bone disease using high resolution computerized microtomography $(\mu \mathrm{CT})$. The animals were distributed into four groups: G1 - hyperphosphatemic diet with sun exposure deprivation (n=4), G2 - hyperphosphatemic diet with sun exposure $(n=4), G 3$ - balanced diet with sun exposure deprivation $(n=4)$, and G4 - balanced diet with exposure to sunlight $(n=4)$. The parameters for the trabecular bone (Trabecular Number, Trabecular Thickness, Trabecular Separation, Bone Pattern Factor, Fractal Dimension, Euler Number, Structural Model Index, Degree of Anisotropy, Eigenvalues 1, 2 and 3, and Centroides X, Y and Z), and cortical bone (Number of Closed Pores, Volume of Closed Pores, Surface of Closed Pores, Closed Porosity, Volume of Open Pores, Open Porosity and Total Porosity). The overall results showed that the structure and bone quality of group G3 and G4 were better than those of groups G1 and G2, and that the diet factor influenced more than the sun exposure factor. The computerized microtomography allowed to evaluate the quality of the cortical and trabecular bones of the Pantanal alligator tibia with osteometabolic disease. The diet and sun exposure factors influenced individually the results of the $\mu \mathrm{CT}$ parameters between the groups, demonstrating the functional and structural complexity. Thus, these parameters can contribute to the interpretation of the mechanical behavior of bones and correlate them with the risk of lesions and fractures associated with osteometabolic diseases.
\end{abstract}

INDEX TERMS: $\mu \mathrm{CT}$, alligators, Caiman yacare, bone quality, micro architecture, osteometabolic diseases, clinics.

\footnotetext{
${ }^{1}$ Received on July 5, 2017.

Accepted for publication on August 10, 2017.

${ }^{2}$ Programa de Pós-Graduação em Ciências Veterinárias (PPGVET), Faculdade de Medicina Veterinária (FAVET), Universidade Federal de Mato Grosso (UFMT), Av. Fernando Corrêa da Costa 2367, Bairro Boa Esperança, Cuiabá, MT 78068-900, Brazil.

${ }^{3}$ Laboratório de Epidemiologia Veterinária, Departamento de Medicina Veterinária Preventiva, Faculdade de Medicina Veterinária, Universidade
}

Federal do Rio Grande do Sul (UFRGS), Av. Bento Gonçalves 9090, Porto Alegre, RS 91540-000, Brazil.

${ }^{4}$ Laboratório de Patologia Animal, Instituto de Ciência da Saúde, Universidade Federal de Mato Grosso (UFMT), Campus Sinop, Av. Alexandre Ferronato 1200, Setor Industrial, Sinop, MT 78557-267, Brazil.

${ }^{5}$ Faculdade de Medicina Veterinária (FAVET), Universidade Federal de Mato Grosso (UFMT), Av. Fernando Corrêa da Costa 2367, Bairro Boa Esperança, Cuiabá, MT 78068-900, Brazil. *Corresponding author: moleta@gmail.com 
RESUMO.- [Avaliação da qualidade óssea de doença osteometabólica experimental em jacarés do pantanal (Caiman yacare) por Microtomografia Computadorizada ( $\mu \mathrm{CT})$.] Microtomografia computadorizada é o exame padrão-ouro para a avaliação da estrutura tridimensional do osso. Este estudo experimental foi desenvolvido para avaliar a estrutura e a qualidade óssea de jacarés-do-pantanal (Caiman yacare) com doença óssea metabólica utilizando a microtomografia computadorizada $(\mu \mathrm{CT})$ de Alta Resolução. Os animais foram distribuídos em quatro grupos, G1 - dieta hiperfosfatêmica com privação de luz solar ( $\mathrm{n}=4), \mathrm{G} 2$ - dieta hiperfosfatêmica com exposição à luz solar (n=4), G3 - dieta balanceada com privação de luz solar (n=4) e G4 - dieta balanceada com exposição à luz solar $(n=4)$. Avaliaram-se os parâmetros para o osso trabecular (Número de Trabéculas, Espessura Trabecular, Separação Trabecular, Fator do Padrão Ósseo, Dimensão Fractal, Número de Euler, Índice do Modelo Estrutural, Grau de Anisotropia, Autovalores 1, 2 e 3 e Centroides X, Y e Z) e osso cortical (Número de Poros Fechados, Volume dos Poros Fechados, Superfície de Poros Fechados, Porosidade Fechada, Volume de Poros Abertos, Porosidade Aberta e Porosidade Total). Os resultados gerais evidenciaram que a estrutura e a qualidade óssea dos grupos G3 e G4 foram superiores aos dos grupos G1 e G2, sendo que o fator dieta influenciou mais do que o fator exposição solar. A Microtomografia Computadorizada permitiu avaliar a qualidade dos ossos cortical e trabecular da tíbia de jacarés do pantanal com doença osteometabólica. Os fatores dieta e exposição solar influenciaram individualmente no resultado dos parâmetros do $\mu \mathrm{CT}$ entre os grupos, demonstrando a complexidade funcional e estrutural. Assim, esses parâmetros podem contribuir na interpretação do comportamento mecânico dos ossos e correlacioná-los com o risco de lesões e fraturas associadas às doenças osteometabólicas.

TERMOS DE INDEXAÇÃO: $\mu$ CT, jacarés do pantanal, Caiman yacare, doenças osteometabólicas, micro arquitetura óssea, qualidade óssea, clínica.

\section{INTRODUCTION}

Bone structure and strength are determined by an intrinsic association of features, such as mass, geometry, and bone quality (Ostrov et al. 2009). The main structural and functional elements that influence these properties are bone remodeling, composition of the organic and inorganic matrix, mineral distribution, and microscopic injuries. These features are interdependent and increase the complexity of skeleton formation in animals (Compston 2006).

Laboratory diagnosis of bone diseases has evolved through computer programs that use mathematic algorithms to support comprehension of bone structure, which contributes to understanding the process of bone formation, remodeling, and injuries. These systems for image capturing and processing replicate tridimensional configuration of organs through quantitative parameters to express and assess the main structural elements of bones (Compston 2006).

Computerized microtomography $(\mu \mathrm{CT})$ is one assessment system widely used in bone evaluation (Ritman 2011, Syahrom et al. 2011, Blok et al. 2013, Cesar et al. 2013, Paolillo 2013, Fernandes 2014, Paolillo et al. 2014), and it is considered the gold standard examination for this purpose
(Bouxsein et al. 2010, Fuller et al. 2015). Results from this exam are based on quantitative parameters for both cortical and trabecular bone (Klinck et al. 2008).

The parameters of $\mu \mathrm{CT}$ are morphometric indexes obtained from 3D images. Manufacturers develop software according to their own algorithms which generate different results between companies for the same parameters (Bouxsein et al. 2010). They refer to morphometric units: trabeculae (trabecular bone) with the definition of shape, number, volume, density, separation, number of connections in between, the average thickness, and the estimate force and resistance; related to the osteon (cortical bone) by measuring porosity and the definition of pore profile as open and closed (Bouxsein et al. 2010, Fuller et al. 2015).

Osteometabolic diseases (OMD) are highly frequent within Pantanal alligators (Caiman yacare) husbandry farms particularly within animals of 4 and 12 months of age (Paranzini et al. 2008, Aleixo 2000). This incidence is related to the variation of mineral composition in their diets (Verdade 1997, Jacinto et al. 2008, Paranzini et al. 2008) intending to avoid mineralization of the osteoderms in their skin (Brazaitis 1987, Marques \& Monteiro 1995, Sarkis-Gonçalves et al. 2002). The aim of this research was to perform an experimental study in Pantanal alligators (Caiman yacare) with osteometabolic diseases (OMD) using high-resolution computerized microtomography $(\mu \mathrm{CT})$ to assess bone structure and quality.

\section{MATERIALS AND METHODS}

The study was performed at the Veterinary Pathology Laboratory (LPV-UFMT) in the Veterinary Hospital of the Federal University of Mato Grosso between 2013 and 2017. The experiment used 16 Pantanal alligators (Caiman yacare) which were approximately three years old and were donated by a husbandry farm from Cáceres, Mato Grosso, with environmental certification (CTF/AINDA) No. 591747 and authorization from the Ethics Committee for Animal Use (CEUA-UFMT) no. 23108.118844/15-06.

The research used a two-by-two experimental design, such as dietary factor (balanced vs. hyperphosphatemic) and sun exposure factor (yes vs. no). The hyperphosphatemic diet consists of bovine spleen and lungs and has an average calcium:phosphorus ratio of 1.0:3.5, whereas the balanced diet also contains bovine organs with supplementation of minerals and vitamins that balance the diet with an average calcium:phosphorus ratio of 1.8:1.0 according to Aleixo (2000). The composition of both diets was analyzed by the Agroanalysis Laboratory in Cuiabá, Mato Grosso. Diets were provided ad libitum during five days of the week for all groups. Sun exposure was controlled in two housing environments, with or without sun exposure according to the study group.

All alligators were individually identified with microchips (FDX-B ISO-Compliant transponder ${ }^{\circledR}$ ). They were housed in four plastic tanks of 500 liters that were inclined in order to have half of the floor area covered by water varying from 1 to $15 \mathrm{~cm}$ of depth (Soares 2010). The study groups were sorted according to Group 1 - hyperphosphatemic diet associated to sunlight deprivation; Group 2 - hyperphosphatemic diet associated to sunlight exposure; Group 3 - balanced diet associated with sunlight deprivation; Group 4 - balanced diet associated to sunlight exposure (Moraes et al. 2015).

After six months of procedures, the alligators were euthanized in conformity with all criteria established by the Federal Council of Veterinary Medicine (CFMV 2012), as well as, necropsied. Samples of their left tíbia were dissected and kept in 10\% buffered formalin. 
Four samples of the tíbia were analyzed by computerized microtomography $(\mu \mathrm{CT})$ for each study group with a cone beam x-ray machine, $\mu$ CT 1172 (SKYSCAN ${ }^{\circledR}$, Kontich - Belgium) (http://www.skyscan.be/home.htm) at the Royal Veterinary College (RVC), London, UK.

The resolution of the voxel was $83 \mu \mathrm{m}^{3}(50 \mathrm{KV}, 200 \mathrm{~mA})$ and analysis of bone parameters was performed with the Skyscan software (NRecon, DataViewer, CTAn). Two volume-of-interest (VOIS) were used: middle regions of the proximal tíbia diaphysis and epiphysis aiming to quantitatively and qualitatively analyze the microstructure of the trabecular and cortical bone respectively. Image reconstruction used $1632 \times 1556$ pixels of resolution with pixels of $8.88 \mu \mathrm{m}$ in size and a data volume corresponding to a tridimensional matrix of 1632x1632x1556 pixels. Bone parameters were obtained through a different method for the trabecular and cortical tíbia bone, according to Table 1 and 2 .
Statistical analyses were performed through R software 3.2.2 version. We applied variance analysis (ANOVA) for each parameter of the cortical and trabecular bone considering the following premises: normality, homogeneity, and independence. For those that have not followed the expected premises, non-parametric tests (Kruskal Wallis Test) were applied with a level of significance of $\mathrm{p}<0.05$ for both (R Development Core Team 2015).

\section{RESULTS}

\section{General bone analysis: cortical and trabecular}

For trabecular bone, the average values of Tissue Volume $\left(\mathrm{TV}, \mathrm{mm}^{3}\right)$ were in $\mathrm{G} 1=101.357, \mathrm{G} 2=35.669, \mathrm{G} 3=8.270$, and $\mathrm{G} 4=9.375$, whereas for cortical bone, they were $\mathrm{G} 1=7.144$, $\mathrm{G} 2=7.683, \mathrm{G} 3=8.534$, and $\mathrm{G} 4=9.375$. All groups were statistically different when compared.

Table 1. Experimental design and basic three-dimensional indexes which quantatively describe the estructures of trabecular tibia bone of Pantanal alligators (Caiman yacare)

\begin{tabular}{|c|c|c|c|c|c|c|c|c|}
\hline \multirow{3}{*}{ Trabecular parameters } & \multicolumn{2}{|c|}{ Hyperphosphatemic } & \multicolumn{2}{|c|}{ Balanced } & \multicolumn{4}{|c|}{ Interactions } \\
\hline & Non-exposed & Exposed & Non-exposed & Exposed & HNExHE & HNExBNE & HExBE & BNExBE \\
\hline & G1 & G2 & G3 & G4 & $\mathrm{G} 1 \mathrm{xG} 2$ & G1xG3 & $\mathrm{G} 2 \mathrm{xG} 4$ & G3xG4 \\
\hline Trabecular thickness (Tb.Th, mm) & $0.050^{* *}$ & 0.059 & 0.079 & $0.182^{* * *}$ & 0.94 & 0.35 & $0.0001^{*}$ & $0.0003^{*}$ \\
\hline Trabecular separation (Tb.Sp, mm) & 1.273 & 0.757 & $0.437^{* *}$ & $0.48^{*}$ & 0.37 & $0.035^{*}$ & 0.66 & 0.988 \\
\hline Trabecular number (Tb.N, mm(-1) & 0.742 & 1.106 & $2.508^{*}$ & 1.107 & 0.93 & 0.05 & 1.00 & 0.145 \\
\hline Trabecular pattern factor (Tb.Pf, mm(-1) & 29.488 & 8.575 & -83.680 & -49.944 & 0.97 & 0.06 & 0.22 & 0.999 \\
\hline Centroid (x) (Crd.X, mm) & $2.225^{* * *}$ & 1.641 & 1.817 & 2.062 & 0.44 & 0.71 & 0.68 & 1 \\
\hline Centroid (y) (Crd.Y, mm) & $2.486^{* * *}$ & 1.998 & 1.893 & 2.137 & 0.48 & 0.33 & 0.97 & 0.882 \\
\hline Centroid (z) (Crd.Z, mm) & $18.303^{* * *}$ & 21.588 & 16.672 & 13.859 & 0.87 & 0.98 & 0.32 & 0.913 \\
\hline Structure model index (SMI, none) & 2.301 & 1.411 & $-4.658^{* *}$ & $-8.698^{* * *}$ & 0.97 & $0.025^{*}$ & $0.002^{*}$ & 0.257 \\
\hline Degree of anisotropy (DA, none) & $1.650^{* * *}$ & 1.533 & $1.451^{*}$ & 1.541 & 0.59 & 0.18 & 1.00 & 0.758 \\
\hline Eigenvalue 1 (none, none) & $70.160^{* * *}$ & 21.101 & $3.328^{* *}$ & $0.073^{* * *}$ & 0.80 & $0.0216^{*}$ & $0.0007^{*}$ & $0.049 *$ \\
\hline Eigenvalue 2 (none, none) & $96.866^{* * *}$ & 28.198 & $4.090^{* *}$ & $0.086^{* * *}$ & 0.73 & $0.0145^{*}$ & $0.0005^{*}$ & $0.039 *$ \\
\hline Eigenvalue 3 (none, none) & $107.784^{* * *}$ & 31.684 & $4.602^{* *}$ & $0.112^{* * *}$ & 0.75 & $0.015^{*}$ & $0.0005^{*}$ & $0.049 *$ \\
\hline Fractal dimension (FD, none) & $2.396^{*}$ & 2.377 & 2.520 & 2.357 & 1.00 & 0.74 & 1.00 & 0.559 \\
\hline Number of objects (N. Obj., none) & $43,264.25^{* * *}$ & 227.250 & $308^{*}$ & $5.5^{* * *}$ & 0.28 & 0.09 & 0.07 & 0.237 \\
\hline Euler number (EM, none) & $-28,372.5$ & $-2,952.5$ & $-2,392.75$ & -168.5 & & & & \\
\hline
\end{tabular}

* Estatistically significant differences (ANOVA, Teste Kruskal-Wallis $\mathrm{p}<0.05$ ), HNE $=$ Hyperphosphatemic diet whith out sun exposure, $\mathrm{HE}=$ Hyperphosphatemic diet with sun exposure, BNE = Balanced Diet without sun exposure, $\mathrm{BE}=$ Balanced diet with sun exposure.

Table 2. Experimental design and basic three-dimensional structural indexes which quantatively describe the structures of cortical tibia bone of Pantanal alligators (Caiman yacare)

\begin{tabular}{|c|c|c|c|c|c|c|c|c|}
\hline \multirow{3}{*}{ Cortical parameter } & \multicolumn{2}{|c|}{ Hyperphosphatemic } & \multicolumn{2}{|c|}{ Balanced } & \multicolumn{4}{|c|}{ Interactions } \\
\hline & Non-exposed & Exposed & Non-exposed & Exposed & HNExHE & $\underline{\text { HNExNNE }}$ & HExNE & NNExNE \\
\hline & G1 & G2 & G3 & G4 & $\mathrm{G} 1 \mathrm{xG} 2$ & G1xG3 & $\mathrm{G} 2 \mathrm{xG} 4$ & G3xG4 \\
\hline Number of closed pores (Po.N(cl), none) & 7.25 & 39.75 & $1,281.25$ & 68.25 & 0.860 & $0.02 *$ & 0.810 & 0.610 \\
\hline Volume of closed pores (Po.V(cl), mm3) & 0 & 0.001 & 0.008 & 0.001 & 0.860 & $0.02 *$ & 0.810 & 0.610 \\
\hline Surface of closed pores (Po.S(cl), mm2) & 0.033 & 0.189 & 3.508 & 0.279 & 0.770 & $0.02^{*}$ & 0.850 & 0.680 \\
\hline Closed porosity (percent) (PO, \%) & 1.5 & 4.1 & 48.5 & 3.8 & 0.540 & $0.02 *$ & 1.000 & 0.280 \\
\hline Volume of open pore space (Po.V(op), mm3) & $6.561^{* * *}$ & $6.575^{* * *}$ & $6.909 * * *$ & $7.492^{* * *}$ & 1.000 & 0.994 & 0.912 & 0.975 \\
\hline Open porosity (percent) (Po(op), \%) & $91.805^{* * *}$ & $85.804^{* * *}$ & $80.843^{* * *}$ & $80.216^{* * *}$ & 0.478 & 0.079 & 0.535 & 0.999 \\
\hline Total volume of pore space (Po.V(tot), mm3) & $6.561^{* * *}$ & $6.576^{* * *}$ & $6.917^{* * *}$ & $7.493^{* * *}$ & 1.000 & 0.994 & 0.913 & 0.976 \\
\hline Total porosity (percent) (Po(tot), \%) & $91.807^{* * *}$ & $85.811^{* * *}$ & $80.928^{* * *}$ & $80.224^{* * *}$ & 0.478 & 0.081 & 0.535 & 0.998 \\
\hline
\end{tabular}

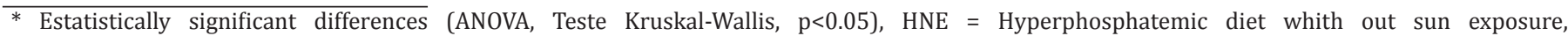
$\mathrm{HE}=$ hyperphosphatemic diet with sun exposure, BNE = Balanced diet without sun exposure, BE = Balanced diet with sun exposure. 
The average values of Bone Volume (BV, $\left.\mathrm{mm}^{3}\right)$ were different for cortical bone: $\mathrm{G} 1=0.584, \mathrm{G} 2=1.107, \mathrm{G} 3=1.617$, and $G 4=1.882$; and for trabecular bone: $G 1=1.528, G 2=1.22$, G3=1.336, and G4=1.882 (Fig.1). Rates for Percent Bone Volume (BV/TV, \%) of cortical bone were: $\mathrm{G} 1=8.19, \mathrm{G} 2=14.19$, G3=19.78, and G4=19.07, while trabecular bone obtained averages as: G1=1.637, G2=6.6, G3=16.78, and G4=19.78 (Fig.2).

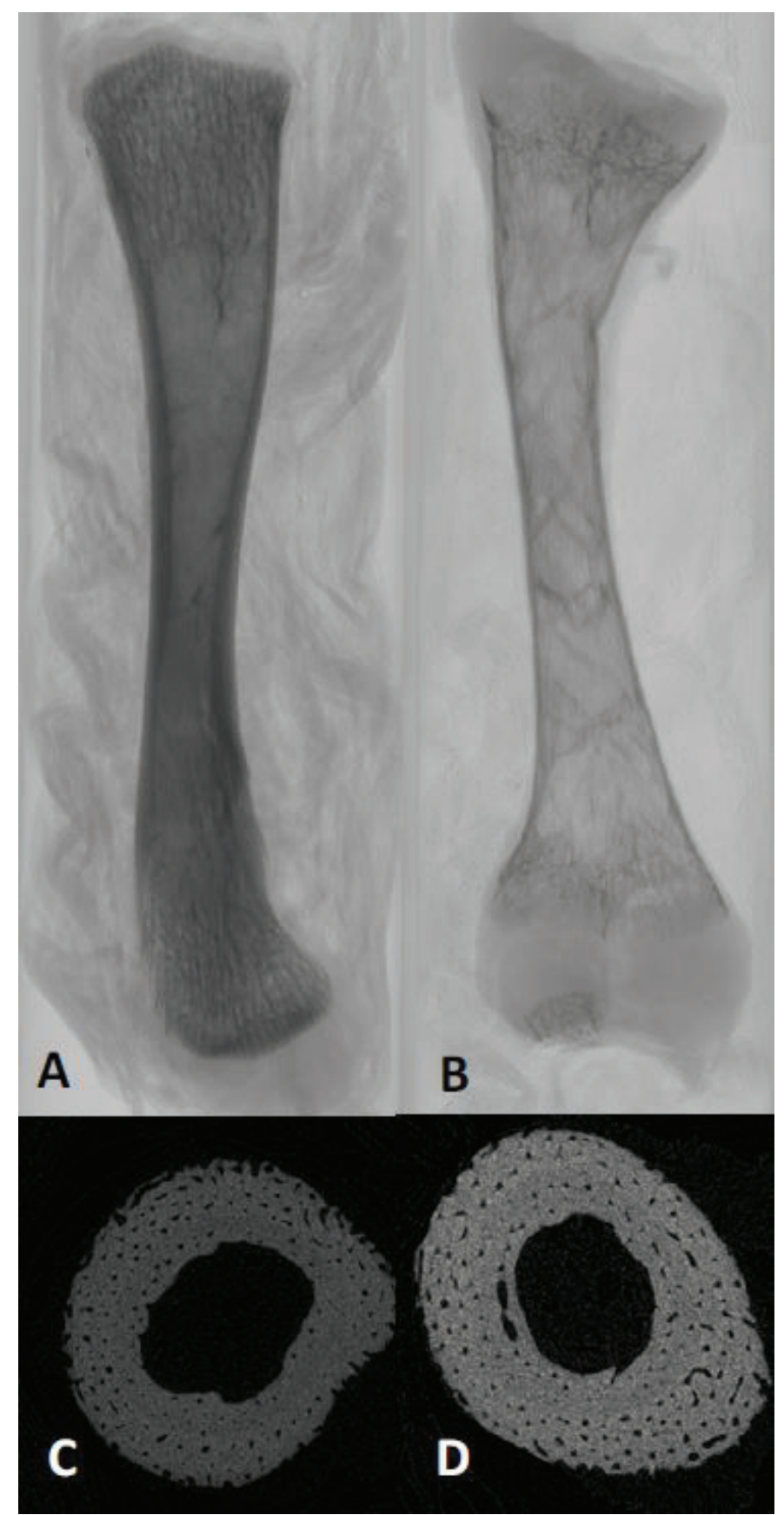

Fig.1. Bone quality evaluation of Pantanal alligators (Caiman yacare) tíbia by computerized microtomography. (A) Group G3 tibia with an adequate distribution of trabecular and cortical bone. (B) Group G1 tibia with a decrease in trabecular (epiphysis) and cortical bone (diaphysis). (C) Cross section of group G3 tibia presenting adequate porosity in cortical bone. (D) Cross section of group G1 tibia with a slight increase in cortical porosity.
Values for parameters of $\mu \mathrm{CT}$ for trabecular and cortical bone as well as their interactions among experimental groups are presented in Table 1 and 2 .

\section{Analysis of trabecular bone structure}

The main properties evaluated $\mu \mathrm{CT}$ of trabecular bone were: density (mass), geometry (spatial distribution and ratio), and resistance.

Density: Trabecular Number (Tb.N.), Trabecular Thickness (Tb.Th.), and Trabecular Separation (Tb.Sp.). Trabecular Number (Tb.N., mm [-1]) for group G3 (2.508) was greater and statistically different $(\mathrm{p}<0.05)$ compared with group G4 (1.107), G1 (0.742), and G2 (1.106). No interactions regarding diet and sun exposure were observed.

The averages for the parameter of Trabecular Thickness (Tb.Th., mm) of Groups G4 (0.182) and G1 (0.050) were statistically different $(\mathrm{p}<0.05)$ when compared to groups G3 (0.079) and G2 (0.059). Also was observed interaction between group G2 and G4 for hyperphosphatemic diet and balanced diet, both under sun exposure $(\mathrm{p}<0.0001)$, and between group G3 and G4 for the balanced diet with sun exposure and without sun exposure $(\mathrm{P}<0.0003)$.

The Trabecular separation (Tb.Sp., mm) of the group G3 $(0.437)$ and $\mathrm{G} 4(0.48)$ was statistically different $(\mathrm{p}<0.05)$ when compared to groups G1 (1.273) and G2 (0.757). It was also observed interaction between Group G1 and G3 regarding hyperphosphatemic diet and balanced diet $(\mathrm{p}<0.035)$ both associated to sun exposure.

Geometry: Bone Pattern factor (Tb. Pf.), Fractal Dimension (FD), and Euler number. All four groups did not differ statistically between themselves $(p>0.05)$ for the Trabecular Pattern factor parameter (Tb.Pf., mm (-1); however the averages for treatments of the group G1 (29.488) and G2 (8.575) was superior compared with those of group G3 $(-83.680)$ and G4 $(-49.944)$. No interaction related to sun exposure was observed.

In Fractal Dimension (FD, none), group G1 (2.396) was statistically different $(\mathrm{p}<0.05)$ from group G3 (2.520), G4 (2.357) and G2 (2.377), and no interaction associated with sun exposure was observed.

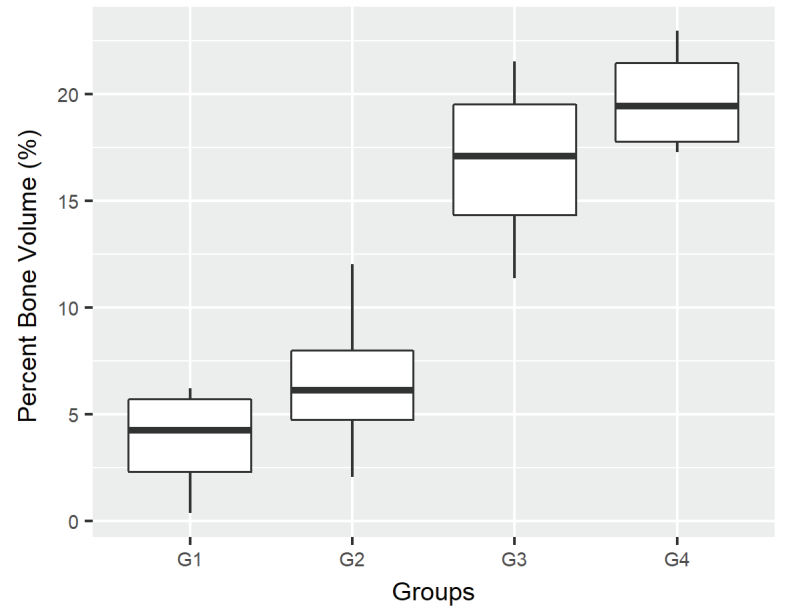

Fig.2. Percent Bone Volume (BV/TV, \%) of trabecular bone of groups G1, G2, G3, and G4 for Pantanal alligator (Caiman yacare) tibia. 
The parameter of Number of Objects (N.Obj., none) for group G3 (308), G4 (5.5) and G1 $(43,264.25)$ was statistically different $(\mathrm{p}<0.05)$ compared to the average of group $\mathrm{G} 2$ (227.25). No interaction related with sun exposure was observed.

Although Euler number could not be statistically estimated, it was observed that the average for group G1 $(-28,372.50)$ was inferior to group G2 $(-2,952.50)$, G3 $(-2,392.75)$, and G4 $(-168.50)$.

Resistance: Structural Model Index (SMI), Degree of Anisotropy (DA), Eigenvalue (1, 2, and 3), and Centroid (Crd. X., Crd. Y. and Crd. Z.). Values for the parameter of Structural model index (SMI, none) in group G1 (2.301) and G2 (1.411) were higher and statistically different $(\mathrm{p}<0.05)$ from those of group G3 (-4.658) and G4 (-8.698). The interaction between group G1 and G3 was related to hyperphosphatemic diet and balanced diet $(\mathrm{p}<0.025)$ both with sun exposure. There was also interaction between group G2 and G4 on hyperphosphatemic diet and balanced diet $(\mathrm{p}<0.002)$ both with sun exposure.

For Degree of Anisotropy (DA, none), group G1 (1.650) and G3 (1.451) was statistically different $(\mathrm{p}<0.05)$ compared with group G4 (1.541) and G2 (1.533). No interaction related to diet, and sun exposure was observed.

The averages for parameter of Eigenvalue 1 (none, none) in group G3 (3.328), G4 (0.073), and G1 (70.160) was statistically different $(\mathrm{p}<0.05)$ compared to the average of group $\mathrm{G} 2$ (21.101). The interaction was also observed between groups G1 and G3 related to hyperphosphatemic diet and balanced $\operatorname{diet}(\mathrm{p}<0.0216)$ both with sun exposure. There was interaction between group G2 and G4 associated with hyperphosphatemic diet and balanced diet $(\mathrm{p}<0.0007)$ both with sun exposure, and also interaction between group G3 and G4 for balanced diet with or without sun exposure $(\mathrm{p}<0.049)$.

The Eigenvalue 2 parameter (none, none) of group G3 (4.090), G4 (0.086), and G1 (96.866) was statistically different $(\mathrm{p}<0.05)$ when compared to the average of group G2 (28.198). Interaction was also observed between group G1 and G3 regarding hyperphosphatemic diet and balanced diet $(\mathrm{p}<0.0145)$, both without sun exposure. There was also interaction between group G2 and G4 on hyperphosphatemic diet and balanced diet $(\mathrm{p}<0.0005)$ both with sun exposure, and interaction between group G3 and G4 on balanced diet with and without sun exposure $(\mathrm{p}<0.039)$.

The average values for Eigenvalue 3 (none, none) of group G3 (4.602), G4 (0.112), and G1 (107.784) were statistically different $(\mathrm{p}<0.05)$ when compared to the average of group G2 (31.684). Interaction occurred between group G1 and G3 on hyperphosphatemic diet and balanced diet $(\mathrm{p}<0.15)$, both without sun exposure. There was also interaction between group G2 and G4 on hyperphosphatemic diet and balanced diet $(p<0.0005)$, both with sun exposure. It was demonstrated that interaction occurred between group G3 and G4 for balanced diet with or without sun exposure $(\mathrm{p}<0.049)$.

\section{Analysis of cortical bone composition}

The main property assessed with $\mu \mathrm{CT}$ in the cortical bone was porosity.

Considering the parameter of Closed Porosity (PO, \%), we observed that the average for group G3 (48.5) was higher compared with the averages of group G1 (1.5), G2 (4.1) and G4 (3.8). Interaction has also been observed between group
G1 and G3 on hyperphosphatemic diet and balanced diet $(\mathrm{p}<0.02)$, both without sun exposure.

The averages of the four groups for Open Porosity (Po. (op) were statistically different from each other $(\mathrm{p}<0.005)$, and the averages for treatments of group G1 (91.805) and G2 (85.804) were superior compared with group G3 (80.843) and G4 (80.216). No interaction related to the diet and sun exposure was observed.

For Total Porosity (Po. (tot), \%), all the four groups were statistically different from each other $(\mathrm{p}<0.005)$. The averages for treatments of group G1 (91.807) and G2 (85.811) were superior when compared with group Grupos G3 (80.928) and G4 (80.224) (Fig.3). No interaction related to the diet and sun exposure was observed.

Regarding the number of Closed Pores (Po.N. (cl), none), we observed that the averages of the groups $\mathrm{G} 3(1,281.25)$ and G4 (68.25) were higher when compared with those of group G1 (7.25) and G2 (39.75); however there was no significance. Interaction was also observed between group G1 and G3 on hyperphosphatemic diet and balanced diet $(\mathrm{p}<0.02)$, both without sun exposure.

Regarding thesurface of Closed Pores (Po.S. (cl), $\mathrm{mm}^{2}$ ), we observed that the average of group G3 (3.508) and G4 (0.279) was higher when compared with those of group G1 (0.033) and G2 (0.189). There was interaction between group G1 and G3 on hyperphosphatemic diet and balanced diet $(\mathrm{p}<0.02)$, both without sun exposure.

Regarding the Open Pores Volume (Po.V. (op), $\mathrm{mm}^{3}$ ), all four groups were statistically different from each other (p<0.005), group G1 (6.561), G2 (6.575), G3 (6.909) and G4 (7.492). No interaction was observed.

\section{DISCUSSION}

Computerized microtomography is a modern laboratory methodology considered the gold standard examination for bone quality assessment (composition, resistance, and geometry) that also allows understanding etiopathology of diseases (Compston 2006, Vasilić et al. 2009, Bouxsein et al. 2010, Liu et al. 2011, Ritman 2011, Syahrom et al. 2011, Gregor et al. 2012, Blok et al. 2013, Cesar et al. 2013, Paolillo 2013, Fernandes 2014, Paolillo et al. 2014, Fuller et al. 2015,

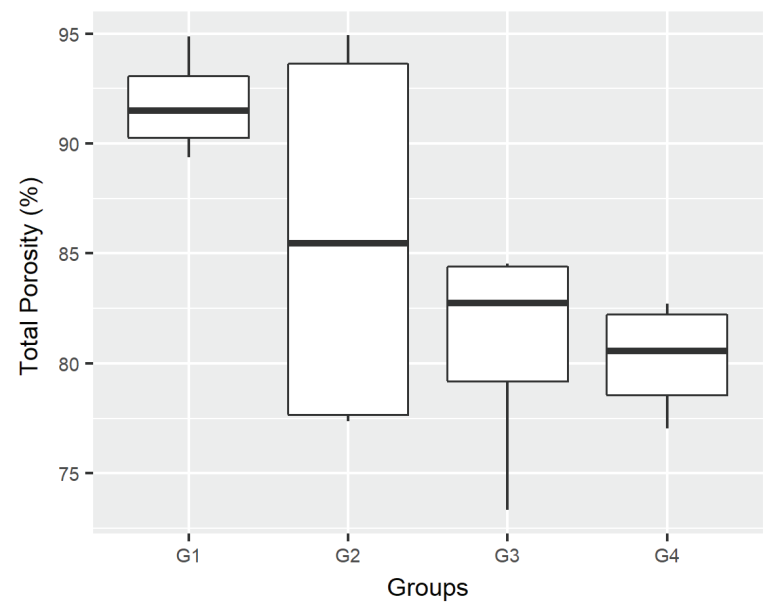

Fig.3. Total porosity (Po (tot), \%)of trabecular bone of groups G1, G2, G3, and G4 for Pantanal alligator (Caiman yacare) tibia. 
Salmon et al. 2015, Longo et al. 2016, 2017, Hsu et al. 2016). This technique has been used to for bone quality assessment in different experimental designs as 87 animal species being 69 mammals, 17 birds, and one alligator (Syahrom et al. 2011, Salmon et al. 2015, Hsu et al. 2016, Longo et al. 2016, 2017). For this study, $\mu \mathrm{CT}$ was applied for assessment of Pantanal alligator tíbia that had been fed with hyperphosphatemic or balanced diets associated or not with sun exposure and that had developed lesions of fibrous osteodystrophy (Fig.4). For a general analysis of the cortical and trabecular bone, the following parameters were considered: Tissue Volume, Bone Volume, and Percent Bone Volume, especially when assessing the relationship between the bone matrix and other tissues.

Tissue Volume was essentially based on bone structure since tíbia samples were dissected (Buie et al. 2007, Larriera et al. 2011, Hsu et al. 2016), which was different from other studies performing in vivo analysis (Link et al. 1999, Wehrli et al. 2003, Buie et al. 2007). The result for Bone Tissue Volume was similar to Bone Volume. This last one assesses the amount of bone mass while Tissue Volume measures the non-mineral tissues. One objective of the study was to comprehend the structural differences between groups. Sample profile was similar among all and therefore this condition did not affect the comparative analysis of the results.

Although tíbia samples were dissected and fixed in formalin solution, they contained non-mineralized material including fibrous tissue that replaced bone matrix and determined fibrous osteodystrophy (McGavin \& Zachar 2013). One of the main mechanisms involved with the etiopathogeny is the change in the calcium and phosphorus ratio in the diet, one of the experimental components in this study. Another aspect to be analyzed in this study is the difference observed between group G1 and group G2. Even though it was not statistically different, it could be associated with the effect of sun exposure between these two groups.

The Percent Bone Volume parameter determines the ratio of bone volume within the Volume-of-Interest Object that is used to measure bone mass related to non-mineralized tissue of the sample (Cesar et al. 2013, Hsu et al. 2016, Longo et al. 2017). In this study, the percentage in group G3 and G4 were higher for both trabecular bone and cortical bone compared to group G1 and G2. If the presence of muscular tissue were considered, the relative difference between these groups would probably be much higher. This decrease in bone mass was similar to other studies performed in human vertebrae (Cesar et al. 2013) with osteopenia and osteoporosis, and in animals (Hsu et al. 2016, Longo et al. 2016).

\section{Trabecular bone analysis}

The bone density property was interpreted as the combination of the following parameters: Trabecular Number, Trabecular Thickness, and Trabecular Separation.

The Food and Drug Administration (FDA/USA) recommends using ovariectomized mice as the clinical model for osteoporosis/osteopenia studies (Thompson et al. 1995). Trabecular changes are primarily observed due to the rapid bone metabolism rate related to the cortical bone (Longo et al. 2016).

The parameters allow us to understand the filling process of three-dimensional space by trabeculae. The observation of bone density of the trabecular bone in our study demonstrated the evident importance of the balanced diet for groups G3 (without exposure) and G4 (with sun exposure) compared to the hyperphosphatemic diet in groups G1 (without exposure) and G2 (with sun exposure) for the growth of Pantanal alligators.

For Trabecular Number, the biggest difference occurred between group G3 $(2.508 \mathrm{~mm})$ and G1 $(0.742 \mathrm{~mm})$ of $1.766 \mathrm{~mm}$, both without sun exposure, whereas between group G4 $(1.107 \mathrm{~mm})$ and G2 $(1.106 \mathrm{~mm})$ was $0.001 \mathrm{~mm}$, both with sun exposure. On the other hand, the difference between G3 and G4 was $1.401 \mathrm{~mm}$. The factor of sun exposure did not influence this parameter. This might be explained by a possible misleading effect, the case of a random error or even that the exposure possibly does not influence this aspect.

For Trabecular Thickness, the biggest difference occurred between groups G4 $(0.182 \mathrm{~mm})$ and $\mathrm{G} 1(0.050 \mathrm{~mm})$ of $0.132 \mathrm{~mm}$, whereas the difference of G3 $(0.079 \mathrm{~mm})$ and G2 (0.059) was $0.02 \mathrm{~mm}$. Balanced diet effect on G4 and G3 demonstrated a far superior average thickness on G1 and G2. Probably, for this parameter, the effect of sun exposure had occurred between (G3 and G4) and (G1 and G2), with differences of $0.103 \mathrm{~mm}$ and $0.009 \mathrm{~mm}$ respectively.

For Trabecular Separation, the biggest difference occurred between group G1 $(1.273 \mathrm{~mm})$ and G3 $(0.437 \mathrm{~mm}) 0.836 \mathrm{~mm}$,

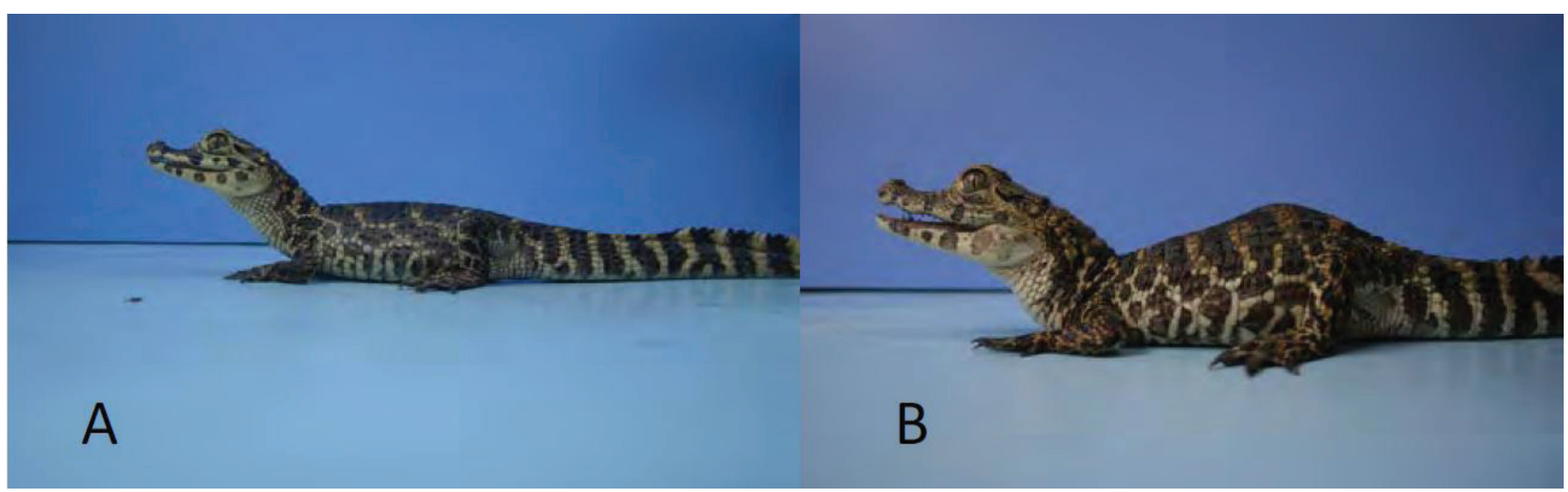

Fig.4. Osteometabolic disease in Pantanal alligators (Caiman yacare). (A) Offspring fed with balanced diet and sun exposure. (B) Alligator fed with a hyperphosphatemic diet without sun exposure presenting arching back as a result of osteometabolic diseases (OMD). 
both without sun exposure. In other words, this proves again that hyperphosphatemic diet negatively impacted the structure of the trabeculae, creating larger distances between them compared to groups with balanced diets. However, the difference between groups with a balanced diet, G3 (without sun exposure) and G4 (0.480mm, with sun exposure), was $0.043 \mathrm{~mm}$, showing a similar pattern with Trabecular Number related to sun exposure factor.

Several studies have demonstrated that osteopenic and osteoporotic bone present higher values for Trabecular Separation and lower values for Trabecular Numberand Trabecular Thickness when compared to normal bone (Cesar et al. 2013, Hsu et al. 2016, Longo et al. 2016). Recent studies have demonstrated that the results in ovariectomized groups were inferior (Tb.Th and Tb.N) and superior (Tb.Sp), both statistically different from the control groups (Longo et al. 2016, Hsu et al. 2016).

Even though the results for microtomography are individual, the analysis of factors, such as diet and sun exposure, in experimental groups must be performed based on the structural and/or functional characteristics through the interpretation of more than one parameter (Parfitt et al. 1987, Hahn et al. 1992). In this study, bone density of trabecular bone was clearly distinct among groups. However, for Trabecular Thickness, the results of two factors were evident, but on the other hand, for parameters of Trabecular Separation and Trabecular Number, only the diet factor influenced the interpretation of results.

Another characteristic of trabecular bone is the Geometry of bone mass. The parameters considered for the assessment of this characteristic were: Bone Pattern Factor, Euler Number, and Fractal Dimension.

Stability of trabecular bone depends not only on the quantity of bone tissue but also on the three-dimensional orientation and trabecular connectivity (Hahn et al. 1992). Bone Pattern Factor assesses the plate and rod trabecular shapes through the ratio of concave surface (values below zero) and convex (values above zero). Convex structures indicate a pattern of poorly connected trabeculae, while concave structures result from a well-connected bone pattern (Hahn et al. 1992). We identified in our study that the groups G3 and G4 presented negative values, whereas G1 and G2 presented positive values. The G3 (without sun exposure) presented the highest concavity index compared to G4 (with sun exposure), both on the balanced diet. Thus, we concluded that diet interferes on trabecular stability and that we did not find any influence of the exposure factor. The smaller the bone volume is, the bigger would the Trabecular Pattern Factor be, and this parameter may provide information on initial stages of bone loss in osteometabolic diseases (PompesiusKempa et al. 1989, Vogel et al. 1989). According to Hahn et al. (1992), similar results were observed for men and women with bone loss due to osteoporosis and subsequent increase Trabecular Pattern Factor. The difference in this parameter between men and women cannot be demonstrated at any age because there is an increase of Trabecular Pattern Factor in women after menopause and this increase intensifies as women ages (Hahn et al. 1992).

Connectivity is a geometric property that provides information about the structure of the inter-trabecular space. Euler Number is a geometric measurement that may provide an estimation of connectivity degree (Arcaro 2009). If no change occurs (addition or removal of trabeculae), it will remain constant and this is known as topological property (Odgaard \& Gundersen 1993, Odgaard 1997). For the present study, groups G1 $(-28,372.5)$ and G2 $(-2,952.5)$ exhibited a pattern, named solid torus, superior to groups G3 $(-2,392.75)$ and G4 $(-168.5)$. In other words, they have lower connectivity and larger inter-trabecular space, demonstrating a less organized microarchitecture. This result indicates that changes occurred among groups probably due to the balanced diet effect on groups G3 and G4 compared to the hyperphosphatemic diet that reduced the changes on the topological pattern.

The British mathematician, Lewis Richardson, described a constant that measures irregular figures in all forms. Mandelbrot named this constant as Fractal Dimension (Fazzalari \& Parkinson 1996). According to Fazzalari \& Parkinson (1996), the fractal analysis is a good method to describe the complex metabolic changes in the structure of trabecular bone, which increases in normal bones compared to osteoporotic bones. In our study, despite the difference, there was no significant difference between groups and therefore it was not possible to use this parameter to comprehend connectivity, possibly due to the number of samples.

The Structural Model Index demonstrates the degree of trabecular structure in plate or rod shape (Salmon et al. 2015). The plate has a value close to zero prone to flattening, while the rod shape has values above three with a tendency to become cylindrical. In our study, groups G3 and G4 presented negative values, whereas groups G1 and G2 had values close to 3. According to Salmon et al. (2015), the mechanical competence of the bone depends on the shape of the trabeculae, being plates mechanically superior to rods. This pattern was evidenced in our study and thus sun exposure (G4) was superior and statistically different from G3 (without sun exposure), both with high rates of plate formation.

The degree of anisotropy among groups revealed different and statistically different values. However, all of them demonstrated structures with an anisotropic pattern typically known for trabecular bone (Harrigan \& Mann 1984, Odgaard 1997), indicating the distribution of collagen fibers arranged towards any direction according to Wolff's Law. In other words, this is an adaptive process and mechanical response of the bone (Frost 1994, Diniz et al. 2006). Despite the differences perceived through other parameters, this indicated that the adaptive process was similar in all groups.

Eigenvalue 1, 2, and 3 defines the three-dimensional rays of the main resistance structure of the bone. According to Cesar et al. (2013), the Eigenvalue 3 was greater than the Eigenvalues 1 and 2, indicating a tendency of symmetry transversely isotropic that is usually associated with the direction preferably oriented by gravity. In our study, the Eigenvalues 1, 2, and 3 for the hyperphosphatemic diet in groups G1 and G2 were superior to those from the balanced diet (G3 and G4), indicating that the diet factor determined a change in the orientation of the trabecular structure and thus making G1 and G2 more isotropic than G3 and G4. Probably, the explanation for this orientation change is due to the replacement of bone tissue for a fibrous matter, which is part of the mechanism for fibrous osteodystrophy (Moraes et al. 2015). Several studies have also demonstrated that osteopenic and osteoporotic bones presented greater values for Degree of 
Anisotropy, Eigenvalue 1, 2, and 3 when compared to normal bones (Cesar et al. 2013, Hsu et al. 2016, Longo et al. 2016).

Results for Centroid (X, Y, and Z) were considered atypical and did not allow adequate analysis.

\section{Cortical bone analysis}

The microstructure of the cortical bone is constituted of a net of pores, which cannot be determined by 2D analytical methods (Peyrin et al. 2011). Normal cortical porosity is classified in three main cavities: canaliculi (below $1 \mu \mathrm{m}$ in diameter), osteocytic gaps (from 10 to $30 \mu \mathrm{m}$ in diameter), and Volkmann/Havers channels (from 40 to $100 \mu \mathrm{m}$ in diameter). The classification of an osteoporotic bone is based on measurements that are greater than those previously mentioned (Wang \& Ni 2003, Rajapakse et al. 2015).

Cortical porosity contributes to all mechanical properties and bone strength (Larriera et al. 2011, Wehrli et al. 2003). On the other hand, increase in porosity is the main aspect of fracture risk (Bala et al. 2016). For this experiment, the cortical bone analysis was performed within the assessment of bone porosity property.

Total Porosity (\%) was superior in groups with hyperphosphatemic diet, G1 (91.8) and G2 (85.8) 88.8\% on average, while balanced diet groups, G3 (80.9) and G4 (80.2), obtained $80.55 \%$ average. This indicates that the diet factor truly influenced the increase in cortical cavitation. Differently, the sun exposure factor, on groups G1 and G2, revealed a difference of $6 \%$ and a difference of $0.7 \%$ on groups $\mathrm{G} 3$ and G4. We can conclude that in this parameter the sun exposure factor might have contributed more for hyperphosphatemic diet than for balanced diet.

An open pore is the one that does not have bone tissue around itself. On the other hand, a closed pore corresponds to the filling of bone tissue around a cortical pore. The open and the closed pores support the comprehension of total porosity (Bala et al. 2016). In this study, groups G1 and G2, fed with a hyperphosphatemic diet, obtained average values on open and closed porosity that were superior to groups G3 and G4 with a balanced diet.

Structural parameters of the Closed Pores (Number, Surface, and Volume) demonstrated that G3 and G4, compared to G1 and G2, had higher number and inferior surface of closed pores. Probably, this is due to the intense osteolytic activity and the transformation of small pores into large pores (Larriera et al. 2011, Palacio-Mancheno et al. 2014). The parameter of Volume for closed pores was not analyzed.

Regarding the structure of open pores, we analyzed the parameter of Open Pore Volume and, in this analysis; we perceived statistical difference among groups. Groups G3 and G4 obtained higher volume compared to G1 and G2, representing a more organized three-dimensional structure in animals that were fed with a balanced diet. However, there are limited studies that support the analysis of this parameter for cortical bone.

\section{CONCLUSIONS}

Computerized microtomography allowed the assessment of the quality of the cortical and trabecular tíbia of Pantanal alligators with osteometabolic disease.

Dietary factors and sun exposure individually influenced the results of the parameters for $\mu \mathrm{CT}$ among groups, showing the functional and structural complexity.
These parameters may contribute to the interpretation of the mechanical bone behavior and to the correlation with injury and fracture risk associated with osteometabolic diseases.

Acknowledgements.- The authors thank the Cooperativa de Creadores de Jacaré do Pantanal - Coocrijapan for provide Caiman yacare for this study. To Prof. Victor Manuel Aleixo (IFMT, Cáceres, MT) for the technical support in the nutritional formulations for C.yacare; To the Royal Veterinary College (RVC), London, for executing the $\mu \mathrm{CT}$; To the National Council of Scientific and Technological Development CNPq (Process 309286/2010-7 and 474375/2010-2) for the financial support.

\section{REFERENCES}

Aleixo V.M. 2000. Efeitos do uso de farelo de soja e de sistemas de alimentação sobre o desempenho de filhotes de Jacaré do Pantanal Caiman yacare (Daudin, 1802). Dissertação de Mestrado, Universidade Federal de Lavras, Lavras, MG. 92p.

Arcaro K. 2009. Característica de Euler-Poincaré para estimar a conectividade da estrutura do osso trabecular. Dissertação de Mestrado, Universidade Federal do Rio Grande do Sul, Porto Alegre, RS. 104p.

Bala Y., Lefevre E., Roux J.P., Baron C., Lasaygues P., Pithioux M., Kaftandjian V. \& Follet H. 2016. Pore network architecture determines cortical bone elasticity during growth and aging. Proceedings 22nd Congress of the European Society of Biomechanics, Lyon, France.

Blok Y., Gravesteijn F.A., Van Ruijven L.J. \& Koolstra J.H. 2013. Microarchitecture and mineralization of the human alveolar bone obtained with microCT. Arch. Oral Biol. 58(6):621-627. http://dx.doi.org/10.1016/j. archoralbio.2012.10.001. PMid:23123067.

Bouxsein M.L., Boyd S.K., Christiansen B.A., Guldberg R.E., Jepsen K.J. \& Muller R. 2010. Guidelines for assessment of bone microstructure in rodents using micro-computed tomography. J. Bone Miner. Res. 25(7):1468-1486. http://dx.doi.org/10.1002/jbmr.141. PMid:20533309.

Brazaitis P. 1987. The identification of crocodilian skins and products, p.373386. In: Webb G., Manolis S.C. \& Whitehead P.J. (Eds), Wildlife Management: Crocodiles and Alligators. Surrey Beatty and Sons, Sydney.

Buie H.R., Campbell G.M., Klinck R.J., MacNeil J.A. \& Boyd S.K. 2007. Automatic segmentation of cortical and trabecular compartments based on a dual threshold technique for in vivo micro-CT bone analysis. Bone 41(4):505515. http://dx.doi.org/10.1016/j.bone.2007.07.007. PMid:17693147.

Cesar R., Boffa R.S., Fachine L.T., Leivas T.P., Silva A.M.H., Pereira C.A.M., Reiff R.B.M. \& Rollo J.M.D.A. 2013. Evaluation of trabecular microarchitecture of normal osteoporotic and osteopenic human vertebrae. Procedia Eng. 59:6-15. http://dx.doi.org/10.1016/j.proeng.2013.05.087.

CFMV 2012. Dispõe sobre procedimentos e métodos de eutanásia em animais e dá outras providências. Conselho Federal de Medicina Veterinária. Resolução nº 1000, de 11 de maio de 2012.

Compston J. 2006. Bone Quality: what is it and how is it measured? Arq. Bras. Endocrinol. Metab. 50(4):579-585. http://dx.doi.org/10.1590/ S0004-27302006000400003. PMid:17117283.

Diniz S., Dionísio V.C., Nicolau R.A. \& Pacheco M.T.T. 2006. Propriedades mecânicas do tecido ósseo: uma revisão bibliográfica. Anais IX Encontro Latino Americano de Iniciação Científica e V Encontro Latino Americano de Pós-graduação, Vale do Paraíba.

Fazzalari N.L. \& Parkinson I.H. 1996. Fractal dimension and architecture of trabecular bone. J Pathol. 178(1):100-105. http://dx.doi.org/10.1002/ (SICI)1096-9896(199601)178:1<100::AID-PATH429>3.0.CO;2-K. PMid:8778308.

Fernandes P.G. 2014. Aplicação da microtomografia computadorizada para a análise morfométrica bi e tridimensional na avaliação da perda óssea experimental em ratos. Tese de Doutorado, Universidade de São 
Paulo, Ribeirão Preto, SP. 124p. http://dx.doi.org/10.11606/T.58.2014. tde-15072014-165529.

Frost H.M. 1994. Wolff's law and bone's structural adaptations to mechanical usage: an overview for clinicians. Angle Orthodontist 64(3):175-188. PMid:8060014.

Fuller H., Fuller R. \& Pereira R.M.R. 2015. Tomografia computadorizada quantitativa periférica de alta resolução para avaliacão de parâmetros morfológicos e funcionais ósseos. Revta Bras. Reumatol. 55(4):352-362. http://dx.doi.org/10.1016/j.rbr.2014.07.010.

Hahn M., Vogel M., Pompesius-Kempa M. \& Delling G. 1992. Trabecular bone pattern factor: a new parameter for simple quantification of bone microarchitecture. Bone 13(4):327-330. http://dx.doi.org/10.1016/87563282(92)90078-B. PMid:1389573.

Harrigan T.P. \& Mann R.W. 1984. Characterization of microstructural anisotropy in orthotropic materials using a second rank tensor. J. Mater. Sci. 9(3):761-767. http://dx.doi.org/10.1007/BF00540446.

Hsu P.Y., Tsai M.T., Wang S.P., Chen Y.J., Wu J. \& Hsu J.T. 2016. Cortical bone morphological and trabecular bone microarchitectural changes in the mandible and femoral neck of ovariectomized rats. PLoSOne 11(4):1-13. http://dx.doi.org/10.1371/journal.pone.0154367. PMid:27127909.

Jacinto M.A.C., Coutinho M.E., Vicente F.S., Delben A.A.S.T., Andrade T.C.B. \& Oliveira A.R. 2008. Influência do sistema de produção sobre a formação de osteodermos no couro em jacaré-do-pantanal (Caiman yacare, Daudin). Anais 45a Reunião Anual da Sociedade Brasileira de Zootecnia, Lavras, MG. Available in <http://www.sbz.org.br/visualizar.php?idiom=pt\&artigo=5721> Accessed on Feb. 16, 2016.

Klinck R.J., Campbell G.M. \& Boyd S.K. 2008. Radiation effects on bone architecture in mice and rats resulting from in vivo micro-computed tomography scanning. Med. Eng. Phys. 30(7):888-895. http://dx.doi. org/10.1016/j.medengphy.2007.11.004. PMid:18249025.

Larriera A.I., Palacio Mancheno P.E., Cardoso L. \& Fritton S.P. 2011. Accurate quantification of cortical bone porosity using High-resolution Micro-CT. Annual Meeting of the Orthopaedic Research Society (ORS), New York, NY. (Poster 2205)

Link T.M., Majumdar S., Grampp S., Guglielmi G., Van Kuijk C., Imhof H., Glueer C. \& Adams J.E. 1999. Imaging of trabecular bone structure in osteoporosis. Eur. Radiol. 9(9):1781-1788. http://dx.doi.org/10.1007/s003300050922. PMid:10602950.

Liu X.S., Shane E., McMahon D.J. \& Guo X.E. 2011. Individual Trabecula Segmentation (ITS): based morphological analysis of microscale images of human tibial trabecular bone at limited spatial resolution. J. Bone Miner. Res. 26(9):2184-2193. http://dx.doi.org/10.1002/jbmr.420. PMid:21557311.

Longo A.B., Sacco S.M., Salmon P.L. \& Ward W.E. 2016. Longitudinal use of micro-computed tomography does not alter microarchitecture of the proximal tibia in sham or ovariectomized Sprague-Dawley rats. Calcified Tissue Int. 98(6):631-641. http://dx.doi.org/10.1007/s00223-016-0113-y. PMid:26860853.

Longo A.B., Salmon P.L. \& Ward W.E. 2017. Comparison of ex vivo and in vivo micro-computed tomography of rat tibia at different scanning settings. J. Orthop. Res. 35(8):1690-1698. http://dx.doi.org/10.1002/jor.23435. PMid:27626898.

Marques E.J. \& Monteiro E.L. 1995. Ranching de Caiman crocodilos yacare no Pantanal de Mato Grosso do Sul, Brasil, p.189-211. In: Larriera A. \& Verdade L.M. (Eds), La Conservacion y el Manejo de Caimanes e Crocodilos de América Latina. Vol.1. Fundación Banco Bica, Santa Fé.

McGavin D. \& Zachar J.F. 2013. Bases da Patologia em Veterinária. 5th ed. Elsevier, Rio de Janeiro, p.949-953.

Moraes L.G., Souza M.A., Silva G.S., Ducatti K.R., Nespoli P.E.B., Pescador C.A., Bezerra K.S. \& Colodel E.M. 2015. Reprodução experimental de doença osteometabólica em jacarés-do-pantanal (Caiman yacare): aspectos clínicos e patológicos. Dissertação de Mestrado, Universidade Federal de Mato Grosso, Cuiabá, MT. 21p.

Odgaard A. 1997. Three-dimensional methods for quantification of cancellous bone architecture. Bone 20(4):315-328. http://dx.doi.org/10.1016/ S8756-3282(97)00007-0. PMid:9108351.

Odgaard A. \& Gundersen H.J.G. 1993. Quantification of connectivity in cancellous bone, with special emphasis on 3D reconstructions. Bone 14(2):173-182. http://dx.doi.org/10.1016/8756-3282(93)90245-6. PMid:8334036.

Ostrov D.A., Magis A.T., Wronski T.J., Chan E.K., Toro E.J., Donatelli R.E., Sajek K., Haroun I.N., Nagib M.I., Piedrahita A., Harris A. \& Holliday L.S. 2009. Identification of enoxacin as an inhibitor of osteoclast formation and bone resorption by structure-based virtual screening. J. Med. Chem. 52(16):51445151. http://dx.doi.org/10.1021/jm900277z. PMid:19630402.

Palacio-Mancheno P.E., Larriera A.I., Doty S.B., Cardoso L. \& Fritton S.P. 2014. 3D Assessment of cortical bone porosity and tissue mineral density using High-Resolution Micro-CT: effects of resolution and Threshold Method. J. Bone Miner. Res. 29(1):142-150. http://dx.doi.org/10.1002/jbmr.2012. PMid:23775635.

Paolillo A.R. 2013. Avaliação por microtomografia de raio-X do reparo ósseo em osteotomia completa de tíbia de ratos após tratamento com ultrassom de baixa intensidade e laser de baixa potência. Tese de Doutorado em Bioengenharia, Universidade de São Paulo, São Carlos, SP. 129p. http:// dx.doi.org/10.11606/T.82.2013.tde-17032014-111640.

Paolillo A.R., Paolillo F.R., Silva A.H., Reiff R.B.M., Bagnato V.S. \& Alves J.M. 2014. Avaliação por microtomografia de raio-x do reparo ósseo em tíbia de ratos após tratamento com lipus e laser. Anais XXIV Congresso Brasileiro de Engenharia Biomédica (CBEB), Uberlândia, MG.

Paranzini C.S., Teixeira V.N. \& Trapp S.N. 2008. Principais distúrbios nutricionais encontrados em répteis cativos: revisão bibliográfica. Unopar Científica, Ciênc. Biol. Saúde 10(2):29-38.

Parfitt A.M., Drezner M.K., Glorieux F.H., Kanis J.A., Malluche H., Meunier P.J., Ott S.M. \& Recker R.R. 1987. Bone histomorphometry: standardization of nomenclature, symbols, and units. J. Bone Miner. Res. 2(6):595-610. http:// dx.doi.org/10.1002/jbmr.5650020617. PMid:3455637.

Peyrin F. 2011. Evaluation of bone scaffolds by micro-CT. Osteoporosis Int. 22(6):2043-2048. http://dx.doi.org/10.1007/s00198-011-1609-y. PMid:21523402.

Pompesius-Kempa M., Hahn M., Vogel M. \& Delling G. 1989. Veränderungen der mikroarchitektur des menschlichen knochens in abhängigeit von alter, geschlecht und diagnose, p.206-210. In: Willett H.G. \& Heuck T.H.W. (Eds), Neuere Ergebnisse in der Osteoloqie. Vol.4. Springer-Verlag, Berlin. http:// dx.doi.org/10.1007/978-3-642-74770-0_32.

R Development Core Team 2015. R: a Language and Environment for Statistical Computing. R Foundation for Statistical Computing, Vienna, Austria. Available in <http://www.R-project.org> Accessed on Feb. 16, 2016

Rajapakse C.S., Bashoor-Zadeh M., Li C., Sun W., Wright A.C. \& Wehrli F.W. 2015. Volumetric cortical bone porosity assessment with $\mathrm{mr}$ imaging: validation and clinical feasibility. Radiology 276(2):526-535. http://dx.doi. org/10.1148/radiol.15141850. PMid:26203710.

Ritman E.L. 2011. Current status of developments and application of microCT. Annu. Rev. Biomed. Eng. 13(1):531-552. http://dx.doi.org/10.1146/ annurev-bioeng-071910-124717. PMid:21756145.

Salmon P.L., Ohlsson C., Shefelbine S.J. \& Doube M. 2015. Structure model index does not measure rods and plates in trabecular bone. Front. Endocrinol. 6:162. http://dx.doi.org/10.3389/fendo.2015.00162. PMid:26528241.

Sarkis-Gonçalves F., Castro A.M.V. \& Verdade L.M. 2002. Descartes de origem animal e o crescimento e ganho de peso do jacaré-de-papo-amarelo, Caiman latirostris (Daudin, 1802), em cativeiro. Scientia Agricola 59(2):243-250. http://dx.doi.org/10.1590/S0103-90162002000200006.

Soares C.E. 2010. Desempenho de filhotes de Jacaré-do-pantanal Caimanyacare (Daudin, 1802) criados em cativeiro sob diferentes densidades de lotação. 
Dissertação de Mestrado, Faculdade de Agronomia Medicina Veterinária e Zootecnia, Universidade Federal de Mato Grosso, Cuiabá, MT. 47p.

Syahrom A., Abdul Kadir M.R., Abdullah J. \& Öchsner A. 2011. Mechanical and microarchitectural analyses of cancellous bone through experiment and computer simulation. Med. Biol. Eng. Comput. 49(12):1393-1403. http:// dx.doi.org/10.1007/s11517-011-0833-0. PMid:21947767.

Thompson D.D., Simmons H., Pirie C. \& Ke H. 1995. FDA Guidelines and animal models for osteoporosis. Bone 17(Suppl.4):125-133. http://dx.doi. org/10.1016/8756-3282(95)00285-L. PMid:8579908.

Vasilić B., Rajapakse C.S. \& Wehrli F.W. 2009. Classification of trabeculae into three-dimensional rodlike and platelike structures via local inertial anisotropy. Med. Phys. 36(7):3280-3291. http://dx.doi.org/10.1118/1.3140582. PMid:19673224.

Verdade L.M. 1997. Manejo e conservação do jacaré-de-papo-amarelo (Caiman latirostris) no Estado de São Paulo, p.222-232. In: Valladares-Pádua C.B.,
Bodmer R.E. \& Cullen Junior L. (Eds), Manejo de Vida Silvestre para a Conservação. CNPq, Brasília, DF.

Vogel M., Hahn M., Pompesius-Kempa M. \& Delling G. 1989. Trabecular microarchitecture of the human spine, p.449-455. In: Willert H.G. \& Heuck F.H.W. (Eds), Neuere Ergebnisse in der Osteologie. Springer, Heidelberg. http://dx.doi.org/10.1007/978-3-642-74770-0_69.

Wang X. \& Ni Q. 2003. Determination of cortical bone porosity and pore size distribution using a low field pulsed NMR approach. J. Orthop. Res. 21(2):312-319. http://dx.doi.org/10.1016/S0736-0266(02)00157-2. PMid:12568964.

Wehrli F.W., Saha P.K., Gomberg B.R. \& Song H.K. 2003. Non-invasive assessment of bone architecture by magnetic resonance micro-imaging based virtual bone biopsy. Proc. IEEE 91(10):1520-1542. http://dx.doi.org/10.1109/ JPROC.2003.817867. 